\title{
Effect of competition in different ages in a progeny test of Pinus taeda L
}

\author{
Efeito de competição em diferentes idades em um teste de progênies de \\ Pinus taeda $L$
}

Paulo Cesar Flores Junior ${ }^{1}$ (D), Vanessa Ishibashi ${ }^{1}$ (D), Jorge Luis Monteiro de Matos $^{1}$ (D), Diego Tyszka Martinez ${ }^{1}$ (D), Antonio Rioyei Higa ${ }^{1}$ (b)

${ }^{1}$ Universidade Federal do Paraná - UFPR, Curitiba, PR, Brasil

Howto cite: Flores Junior, P. C., Ishibashi, V., Matos, J. L. M., Martinez, D. T., \& Higa, A. R. (2020). Effect of competition in different ages in a progeny test of Pinus taeda L. Scientia Forestalis, 48(128), e3290. https://doi.org/10.18671/scifor.v48n128.17

\begin{abstract}
The objective of this work was to identify through spatial analysis the presence of competition in three ages in a progeny test of Pinus taeda and, when necessary, to correct the data using phenotypic models of competition. The progeny test was implemented in 1997, with 120 progenies in a randomized complete block design, with five replications, linear plots of five plants and plant spacing of $2.5 \mathrm{~m} \times 2.5 \mathrm{~m}$. At six, 10 and 20 years of age, the diameter of all individuals in the test was measured at breast height. The evaluation of the competition was performed by the residual auto-correlation coefficients and by the Durbin-Watson test. The presence of competition among individuals in the progeny test was identified only at 20 years and a covariate was used only at this age. Of the six covariates tested only one corrected the competition effect, by the Modified Failure Index. Using the adjusted data it was observed that the classification by the individual genetic value changed the ranking of individuals. It was concluded that in the progeny test conditions, until the age of 10 years the competition effect was not verified, and the adjustment of the competition effect is of great importance in the final age of growth for data analysis aiming at greater efficiency in individual genetic selection in forest breeding programs.
\end{abstract}

Keywords: Spatial autocorrelation; REML/BLUP; Failure index; Individual selection.

\section{Resumo}

O objetivo deste trabalho é avaliar o efeito de competição em um teste de progênies com dados coletados em três idades utilizando seis covariáveis sobre o diâmetro a altura do peito via análise espacial para correta seleção de material genético. O teste foi implantado em 1997 com 120 progênies em delineamento de blocos casualizados, com cinco repetições, parcelas lineares de cinco plantas e espaçamento $2.5 \mathrm{~m} \times 2.5 \mathrm{~m}$. Aos seis, dez e vinte anos foi realizada mensuração do diâmetro a altura do peito de todos os indivíduos do teste. A avaliação da competição foi feita pelo teste de autocorrelação residual pelo teste de Durbin-Watson. Com uso de seis covariáveis apenas uma corrigiu o efeito de competição, sendo ela o Índice de Falha Modificado. Utilizando os dados do teste ajustado pela covariável observou-se que a classificação pelo valor genético sofreu uma alteração do ranqueamento dos melhores indivíduos. Conclui-se que nas condições do teste de progênies não é observada competição até 10 anos de idade. Isso demonstra que o uso de modelos fenotípicos com uso de covariável é de grande importância nas análises de dados em idade final de cultivo e através desta metodologia é possível garantir maior eficiência na seleção dos melhores materiais genéticos.

Palavras-chave: Autocorrelação espacial; REML/BLUP; Índice de falha; Seleção individual.

Financial support: Conselho Nacional de Desenvolvimento Científico e Tecnológico (CNPq), Coordenação de Aperfeiçoamento de Pessoal de Nível Superior (CAPES) and Valor Florestal.

Conflict of interest: Nothing to declare.

Corresponding author: paulocesarfloresjunior@gmail.com

Received: 19 February 2019.

Accepted: 8 October 2019.

Editor: Francides Gomes da Silva Júnior.

(i) This is an Open Access article distributed under the terms of the Creative Commons Attribution License, which permits unrestricted use, distribution, and reproduction in any medium, provided the original work is properly cited. 


\section{INTRODUCTION}

The success of genetic improvement depends on the efficient choice of the best individuals to be the parents of the next generations. The morpho-genetic evaluation of the candidates for selection is one way of identifying individuals with desirable genes. The selection should be based on additive genetic values of the individuals that will be used in the recombination or on the genotypic values of the individuals to be cloned. In this sense, an efficient estimation of genetic parameters is fundamental to the success of any breeding program (Farias Neto et al., 2013).

Progeny tests are tools used by breeders to estimate genetic parameters, to select individuals, and to assess the magnitude and nature of the available genetic variance in order to quantify and maximize genetic gains (Costa et al., 2008). However, most forest selection experiments do not take into account the competition between trees, which can cause an incorrect selection (Pavan et al., 2012).

Although the progeny tests of forest species have a long duration, in the analysis of growth data it is not common to consider the presence and the effects of competition. This is so possibly because there are no routines and consolidated procedures for identifying and correcting these effects. The use of phenotypic competition models is expected to isolate variation due to the environment more efficiently, causing the analysis to express the experimental reality more consistently (Leonardecz-Neto et al., 2003). These models use silvicultural performance or spatial distribution of neighbors as a covariate. However, identifying the covariant and how it adjusts to represent the biological effect is a challenge (Pavan et al., 2012).

This work was based on the hypothesis "If there is a competition effect for different ages of $P$. taed $a$ then the spatial auto-correlation should be estimated to assure selective efficiency of superior genotypes". The objective of this work was to identify, through spatial analysis, the presence of competition in three ages in a progeny test of Pinus taeda and, when necessary, to correct the data about diameter at breast height using phenotypic models of competition.

\section{MATERIALS AND METHODS}

\section{Experimental area and genetic material}

The progeny test is located in the municipality of Rio Negrinho, in the State of Santa Catarina, in the region of Planalto Norte. The climate is classified, according to Köppen, as humid subtropical $\mathrm{Cfb}$ with mild summer, without dry season and with frequent severe frosts (Alvares et al., 2013). The mean annual temperature varies from $15.5^{\circ} \mathrm{C}$ to $17.0^{\circ} \mathrm{C}$. In the hottest month (January), the average temperature ranges from $20^{\circ} \mathrm{C}$ to $22^{\circ} \mathrm{C}$ and in July (coldest month), the average temperature varies from $12^{\circ} \mathrm{C}$ to $14^{\circ} \mathrm{C}$ (Bognola et al., 2008). The soil is classified as typical aluminum humic cambium (Empresa Brasileira de Pesquisa Agropecuária, 2006).

The genetic material used comes from a Clonal Seed Orchard with 19 provenances from Florida, 41 from Georgia, 27 from Louisiana and 28 from Zimbabwe and with five commercial controls, totaling 120 progenies. The progeny test was installed in a randomized complete block design with five replications and linear plots with 5 plants, spacing of $2.5 \mathrm{~m} \times 2.5 \mathrm{~m}$. The test has two border lines. Measurements of the diameter variable of all subjects were performed at six, 10 and 20 years of age and were taken at breast height (DAP, cm).

\section{Estimation of spatial autocorrelation}

The autocorrelation coefficients between residues in the directions of the rows or between columns $(\rho \mathrm{L})$, columns or between rows $(\rho C)$, and the value of the $\mathbf{d}$ statistic for the Durbin-Watson residue independence test were obtained with the aid of the SELEGENREML/BLUP $®$ software model of statistical analysis (Resende, 2007a). The value of the $\mathbf{d}$ statistic is defined as described in Equation 1, where $L$ is the positioning order of the plot in 
the experiment and lays the ordered residues in the space. The residues (ri) were obtained via model 1 (Equation 3 ) of the SELEGEN - REML/BLUP® software considering zero in the analysis. The relation between $d$ and $\rho$ is expressed by Equation 2 .

$$
d=\sum_{i=1}^{n}\left(r_{i}-r_{i-1}\right)^{2} / \sum_{L=l}^{n} r_{i}^{2}
$$

$d=2(1-\rho)$

The calculated value of $\mathbf{d}$ was compared with theoretical values with $(n-1)$ degrees of freedom, where $\mathbf{n}$ is the number of data. The values of $\mathbf{d L}$ (lower $\mathbf{d}$ ) and $\mathbf{d} \mathbf{U}$ (upper $\mathbf{d}$ ) are given in tables associated with certain levels of significance. For hypothesis HO: $\rho=0$ there is no auto-correlation of residues. For hypothesis Ha: $\rho>0$ the decision rule $d$ is given by: if $d \leq d L$, it rejects $\mathrm{HO}$ and auto-correlation is positive, if $\mathrm{d} \geq \mathrm{dU}$, it accepts $\mathrm{HO}$ and auto-correlation is null and if $\mathrm{dL}<\mathrm{d}<\mathrm{dU}$ the test is inconclusive. For hypothesis Ha: $\rho<0$ the decision rule is equivalent, but by using (4-d) rather than $d$ (Resende, 2007b).

\section{Estimation of genetic parameters}

The genetic analysis of the data collected in the progeny test was carried out using the SELEGEN - REML/BLUP ${ }^{\circledR}$ software. For the selection of individuals and parents in open pollinated progenies by site, we used the statistical model 1 (Equation 3 ) where $y$ is the data vector, $r$ is the vector of the effects of replication (assumed as fixed) added to the general mean, $a$ is the vector of individual additive genetic effects (assumed to be random), $p$ is the vector of plot effects (assumed to be random), and $\varepsilon$ is the vector of (random) errors or residues. Capital letters represent the incidence matrices for these effects (Resende, 2007a). For the estimation of the genetic parameters the zeros were not considered in the analysis.

$y=X r+Z a+W p+\varepsilon$

\section{Covariance analysis}

The covariance analysis were performed using the SELEGEN - REML/BLUP® software using statistical model 131 (Equation 4), where $y$ is the data vector, $r$ is the vector of the repetition effects (assumed as fixed) added to the (a) is the vector of individual additive genetic effects (assumed to be random), $p$ is the vector of plot effects (assumed to be random), $\varepsilon$ is the vector of (random) errors or residues. The coefficient $\beta$ refers to the regression associated with the covariate. Capital letters represent the incidence matrices for these effects (Resende, 2007a). For analysis of covariance zeros were not considered.

$y=X r+\beta \operatorname{Cov}+Z a+W p+\varepsilon$

The assumptions for covariance analysis are: (i) the covariate values are fixed, measured without error and independent of the treatments, (ii) the regression between the covariate and the variable of interest, after removal of block and treatment differences is linear and independent of blocks and treatments, (iii) the residue is normally and independently distributed, with zero mean and a common variance (Pallant, 2010; Ramalho et al., 2012).

Six covariates were tested:

a) Hegyi Competition Index (IC)

Competition mean (IC) through the distances and performance of the eight possible neighbors of the target plant $\mathrm{i}$ (Leonardecz-Neto et al., 2003). The expression for calculation is given by Equation 6 , where $\mathrm{ICi}$ is the competition index of the target plant $\mathrm{i}$, $\mathrm{Yi}$ is the observed 
value of the target plant $\mathrm{i}, \mathrm{Yj}$ is the observed value of the competing plant $\mathrm{j}$ and $\mathrm{Dij}$ is the distance between plants $\mathrm{i}$ and $\mathrm{j}$.

$$
I C_{i}=\left(\sum_{j=1}^{8} Y_{j} / Y_{i}\right) / D_{i j}
$$

b) Self-competition mean (MAT)

Arithmetic mean of the silvicultural characteristic of the self-competitive trees (Pavan et al., 2012), belonging to the same genetic material (Equation 7), where $\mathrm{Yj}$ is the observed value of the self-competitive plant $j$ and $n$ the number of self-competitive plants.

$$
M A T=\left(\sum_{j=1}^{2} Y_{j}\right) / n
$$

\section{c) Mean 8 (M8)}

For the determination of the mean 8 , the eight (Mean 8 - M8) nearest neighboring trees were considered, being determined by the arithmetical mean of the diameters of the competing trees in question to the tree (Pavan et al., 2012)

d) Number of neighboring plants (NV)

Algebraic sum of the number of surviving neighboring plants (Equation 8 ), $\mathrm{n}$ being the surviving neighboring plant (Resende, 2002).

$$
N V=\sum(n) 8_{j=1}
$$

e) Failure index (IF)

According to Coutinho et al. (2017), to improve the accuracy and to mitigate the effects of the dead neighboring trees, the correction of the failure index (IF) was performed, calculating the IF of each tree and using it as a covariant in the statistical analysis (Pires et al., 2011).

$I F=P 1 . N F L+P 2 . N F C+P 3 . N F D$

f) Modified failure index ( $\left(\mathrm{F}_{\mathrm{MOD}}\right)$

For the modified failure index, the progeny test spacing was more valued to proceed in the correction, if necessary.

$$
I F_{M O D}=2,5(N F L+N F C)+\frac{E L}{\sqrt{\left(E C^{2}+E L^{2}\right)}} \cdot N F D
$$

Since: NFL is the line failure number, NFC is the column failure number, NFD is the diagonal failure number, EL is the line spacing and EC is the column spacing.

\section{Phenotypic adjustments}

The phenotypic values for each surviving individual were adjusted, when necessary,

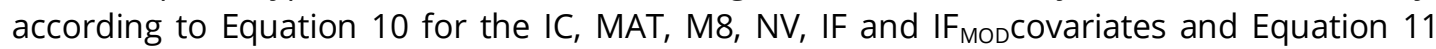
(Resende, 2007b) for covariate NV, $Y_{i j}$ being the phenotypic value measured for each individual and $Y_{i j c}$ the adjusted phenotypic value for each individual. 


$$
\begin{aligned}
& Y_{i j c}=Y_{i j}-\beta\left(x_{i j}-\bar{x}\right) \\
& Y_{i j c}=Y_{i j}-\beta\left(x_{i j}-8\right)
\end{aligned}
$$

\section{RESULTS AND DISCUSSION}

\section{Estimation of spatial autocorrelation}

A decline in survival was observed with the progeny test set-up (Table 1). An explanation for the competition effect could be explained by deviance analysis (data not shown) for survival, but this was not significant for any of the ages, so it would not explain the competition effect linked to mortality.

Table 1. Estimation of spatial autocorrelation by the Durbin-Watson dependency test for the Pinus taeda progeny in the State of Santa Catarina at different ages.

\begin{tabular}{cccc}
\hline & Six years & Ten years & Twenty years \\
\hline Survival $(\%)$ & 98.47 & 88.27 & 71.83 \\
Auto-correlation between columns $(\rho \mathrm{C})$ & $0.03^{\mathrm{ns}}$ & $-0.01^{\mathrm{ns}}$ & $-0.07^{*}$ \\
DWC & 1.97 & 2.03 & 2.13 \\
Auto-correlation between lines $(\rho \mathrm{L})$ & $0.01^{\mathrm{ns}}$ & $-0.01^{\mathrm{ns}}$ & $-0.08^{*}$ \\
DWL & 1.94 & 2.04 & 2.18
\end{tabular}

ns and *: not significant and significant at 5\% probability. Where: DWC: Durbin-Watson between columns, DWL: DurbinWatson between lines.

The negative and significant $\rho C$ and $\rho L$ values are indicative of the presence of competition in the progeny tests, as competition effects between neighboring plants cause negative autocorrelation and d statistic values greater than two. Spatial heterogeneity causes positive correlations (Cappa et al., 2016). Thus, at six and 10 years of age, the results of the Durbin-Watson test were not significant, indicating a lack of competition. The presence of competition was detected only at the age of 20 years (Table 1), that is, the failures caused by the mortality of the individuals provided higher performance of the progenies nearby. Therefore, for this progeny test, phenotypic adjustment should be done only for the age of 20 years. These results differ from those reported by Ishibashi et al. (2017), who reported effects of competition already at 10 years of age in tests of $P$. taeda progenies located in the State of Santa Catarina. These authors report that this effect was random and did not respond to a tendency for a specific family. Leonardecz-Neto et al. (2003) and Pavan et al. (2012), cite that when the assumptions for covariance analysis do not satisfy in full, the covariate should not always be discarded because the appropriate choice of the place to perform the experiment, the reduction of the variance of the experimental error and blocks are as or more important than the error associated with covariate. However, in this work we chose to use only those that met the statistical assumptions of the covariance analysis, that is, as Ishibashi et al. (2017), using covariates where the linear regression coefficient was a significant or a non-significant interaction with the treatments.

\section{Estimation of genetic parameters and covariance analysis}

Genetic parameters were estimated without the use of covariates and also with six covariates (Table 2). After adjustment for each covariate, spatial auto-correlation and its significance were estimated using the Durbin-Watson dependence test. It can be observed that only the $\mathrm{IF}_{\mathrm{MOD}}$ Covariate was able to correct the data set of the test, proving not to be significant. 
The MAT and NV covariables were not sufficient for correction between columns and between rows, since they were significant. On the other hand, the covariant IC adjusted only between columns and the covariates NV and IF between the rows, thus demonstrating that there is no tendency in the test to predict the possible causes of the competition effect.

Table 2. Components of variance and genetic parameters, auto-correlation coefficients of residues between columns $(\rho C)$ and between lines $(\rho L)$ and value of D statistics for rows and columns, with and without the use of the covariate for the variable diameter at breast height (DAP) with their respective regression coefficients ( $\beta$ ) and mean covariant ( $\bar{x}$ Cov) value in a $P$. taeda progeny test 20 years old, planted in Rio Negrinho, in the State of Santa Catarina.

\begin{tabular}{|c|c|c|c|c|c|c|c|}
\hline & $\begin{array}{c}\text { Without } \\
\text { adjustment }\end{array}$ & IC & MAT & M8 & NV & IF & $\mathrm{IF}_{\text {MOD }}$ \\
\hline$\sigma_{a}^{2}$ & 5.84 & 4.33 & 5.31 & 5.81 & 5.21 & 5.30 & 6.02 \\
\hline$\sigma_{\text {parc }}^{2}$ & 0.93 & 2.35 & 0.50 & 0.38 & 0.14 & 0.50 & 0.20 \\
\hline$\sigma^{2}{ }_{e}$ & 24.03 & 6.75 & 24.46 & 21.39 & 22.44 & 24.45 & 22.13 \\
\hline$\sigma_{f}^{2}$ & 30.80 & 13.43 & 30.27 & 27.58 & 27.79 & 30.26 & 28.35 \\
\hline$h^{2}{ }_{a}$ & $0.19+/-0.05$ & $0.32+/-0.06$ & $0.18+/-0.05$ & $0.21+/-0.5$ & $0.19+/-0.05$ & $0.17+/-0.05$ & $0.21+/-0.05$ \\
\hline$c^{2}$ parc & 0.03 & 0.18 & 0.02 & 0.01 & 0.01 & 0.01 & 0.01 \\
\hline$h_{m p}^{2}$ & 0.52 & 0.55 & 0.52 & 0.57 & 0.55 & 0.51 & 0.58 \\
\hline$A C_{\text {prog }}$ & 0.72 & 0.74 & 0.72 & 0.75 & 0.74 & 0.72 & 0.76 \\
\hline$h^{2}{ }_{a d}$ & 0.15 & 0.33 & 0.14 & 0.17 & 0.15 & 0.14 & 0.17 \\
\hline$C V_{g i \%}$ & 8.42 & 7.30 & 8.04 & 8.42 & 7.98 & 8.03 & 8.57 \\
\hline$C V_{e \%}$ & 4.21 & 3.65 & 4.02 & 4.21 & 3.99 & 4.01 & 4.29 \\
\hline$C V_{r}$ & 8.96 & 7.32 & 8.68 & 8.21 & 8.13 & 8.67 & 8.22 \\
\hline$u$ & 28.68 & 28.50 & 28.67 & 28.62 & 28.61 & 28.67 & 28.61 \\
\hline$\rho C$ & $-9.98^{*}$ & $-0.66^{\mathrm{ns}}$ & $-0.06 *$ & $-0.04 *$ & $-0.05^{\mathrm{ns}}$ & $-5.52^{*}$ & $-0.03^{n s}$ \\
\hline$d C$ & 2.13 & 2.01 & 2.12 & 2.08 & 2.1 & 2.09 & 2.07 \\
\hline$\rho L$ & $-14.07 *$ & 5.36 * & $-0.08 *$ & $-0.03^{\text {ns }}$ & $-0.04 *$ & $-3.42^{\text {ns }}$ & $-0.02^{\text {ns }}$ \\
\hline$d L$ & 2.18 & 1.92 & 2.17 & 2.07 & 2.09 & 2.07 & 2.04 \\
\hline$B$ & - & $-6.35^{*}$ & $-0.06 *$ & $-0.39 *$ & $-1.16 *$ & $-0.06 *$ & $0.65 *$ \\
\hline $\bar{x} \operatorname{cov}$ & - & 2.02 & 20.87 & 20.73 & 5.71 & 20.87 & 3.25 \\
\hline
\end{tabular}

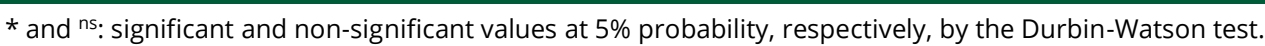

Where: IC: Hegyi competition index, MAT: mean of self-competition, M8: arithmetic mean of competing tree diameters, NV: number of neighboring plants, IF: failure index, IFAJ: adjusted failure index, $\sigma^{2}$ a: additive genetic variance, $\sigma^{2}$ parc: environmental variance between plots, $\sigma^{2}$ e: residual variance within the plot (environmental + non-additive genetics), $\sigma^{2} f$ : individual phenotypic variance, $h^{2} a$ : individual heritability in the narrow sense, $c^{2}$ parc: coefficient of determination of plot effects, $h^{2} \mathrm{mp}$ : average progeny heritability, Acprog: accuracy of progeny selection, h2ad: additive heritability within plot, CVgi: coefficient of variance genotype, CVe\%: coefficient of residual variation, $\mathrm{CV}$ : relative coefficient of variation, $\mathrm{u}=$ Mean of the experiment

The covariates IC and NV resulted in a not significant $\rho C$ and a $\rho L$ significant and positive, thus indicating absence of competition between lines and environmental heterogeneity between columns, respectively (Table 2).

The environmental heterogeneity demonstrated by the Durbin-Watson test is expressed numerically through the genetic parameters using the covariant IC, where $\sigma_{\text {parc }}^{2}$ increased considerably and $\sigma_{f}^{2}$ decreased almost one-third when compared to the data without adjustment and, consequently, increased the coefficient of determination of plot effects ( $c^{2}$ parc). As 
Ishibashi et al. (2017), we also observed a high reduction in residual variance within the plot $\left(\sigma_{e}^{2}\right)$, demonstrating the reason for the absence of correlation between lines. Through this covariate we observed that there was a decrease of $\sigma^{2}{ }_{n}$ demonstrating that the adjusted data decreased the variation between the best and worst genetic material and considerably increased the $h^{2}{ }_{\alpha}$.

According to Pavan et al. (2012), IC provided the most pronounced changes in the experiments evaluated by the author and this indicated that much of the differentiation of genetic materials in progeny tests is due to competition between and within families, a fact also observed by Ishibashi et al. (2017).

For the NV covariant, the $\sigma_{\text {parc }}^{2}$ decreases considerably compared to the unadjusted data and the $\sigma^{2} f$ suffered a small decrease, and the $c^{2}$ parc also decreased, consequently the $C V_{e \%}$ followed this same trend with the increase $A c_{\text {prog }}$ and $h_{a}^{2}$. In a 10-year progeny test evaluated at four sites, two sites were adjusted with this covariate in a study by Ishibashi et al. (2017), thus demonstrating that the use of a covariate does not follow a pattern, and it is necessary to always test different covariates for each genetic and local material.

The MAT provided a small decrease of $\sigma_{a}^{2}$ and $\sigma_{f}^{2}$ but $\sigma_{\text {parc }}^{2}$ reduced almost by half, with $c_{\text {parc }}^{2}$ declining and $\mathrm{CV}_{e \%}$ remaining the same. Obtaining this covariate only detects intra-genotypic competition, not correcting for inter-genotypic competition. The (M8) maintained $\sigma^{2} a$, and $\sigma_{\text {parc }}^{2}$ decreased $60 \%$ when compared to the unadjusted data, and $\sigma^{2} f$ decreased. The $c^{2}$ parc decreased and the $C V_{e \%}$ remained the same and the $h_{a}^{2}$ increased slightly, although it acted in the detection of both intra and inter-genotypic competition, it was not satisfactory for this test (Table 2).

With the use of the covariate IF the $\sigma_{a}^{2}$ decreased and $\sigma_{f}^{2}$ remained, being that $\sigma_{\text {parc }}^{2}$ reduced by approximately half, consequently the $C V_{e \%}$ also decreased. Coutinho et al. (2017) used this covariate in progenies of $P$. taeda half-sibs in an 8 and 15-year test at three sites to increase accuracy and mitigate the effects of dead neighboring trees in order to observe the possibility of early selection. The authors do not report the test of statistical assumptions for the use of the covariate nor the necessity and efficiency of the covariate used.

With the use of the $\mathrm{IF}_{\mathrm{MOD}}, \sigma_{a}^{2}$ presented a small increase, thus achieving a better distribution among the best and worst genetic materials. The $\sigma_{\text {parc }}^{2}$ decreased approximately $80 \%$, thus demonstrating a high correction of the data for intra-genotypic competition, which ends up reflecting the improvement of $c^{2}$ parc, which was reduced by $30 \%$. The experimental coefficient of variation $\left(\mathrm{CV}_{e \%}\right)$ had a small increase, but was of low magnitude and there was an increase in the progeny selection accuracy $\left(A c_{\text {prog }}\right)$ more than the other covariates tested, indicating an expressive genetic control (Table 2).

The individual heritability in the restricted sense $\left(h^{2}\right)$ increased from 0.19 to 0.21 , being considered of medium magnitude. Coutinho et al. (2017) carried out a survey on this important genetic parameter and report that for $P$. taeda species, 0.14 is a reference value. Martinez et al. (2012) obtained mean individual heritability 0.3, Ishibashi et al. (2017) found values ranging from 0.24 to 0.43 . Already Coutinho et al. (2017) verified a variation of this parameter between 0.08 and 0.26 , and they report that the individual heritability decreases with the development of the population, possibly due to the environmental effect of competition between plants that is expressed more with age.

For this genetic material and at this age, the use of the covariable Modified Failure Index is indicated, since it eliminated the effects of autocorrelation between lines and between columns, being that it offers the highest individual heritability value $\left(h^{2}{ }_{a}\right)$, coefficient of determination of the effects of plot $\left(\sigma^{2}\right.$ parc $)$ and shows an acceptable coefficient of variation $\left(C V_{e \%}\right)$.

The regression coefficient associated to the covariate $(\beta)$ presented negative and significant values for five covariables (IC, MAT, M8, NV and IF), indicating a reduction for DAP as intergenotypic competition increases, a fact observed in tests by Leonardecz Neto et al. (2003) and Ishibashi et al. (2017). For this work, the covariable IF $F_{\text {MOD }}$ was the only covariate that presented a positive $\beta$ value and consequently increased the genetic value predicted for DAP.

Among the forms of competition, inter-genotypic and intra-genotypic, the inter-genotypic is the most important for genetic testing since this causes the amplitude between the materials to increase as well as the error between plots. This is an important contribution for future genetic tests in the selection of superior genotypes because as competition influences 
the performance of the materials in a differentiated way between them, this can lead to suppression of some genotypes that could be promising, or in over-valuation of highly competitive materials (Pavan et al., 2012).

The genetic values predicted for diameter at breast height (DBH) using the satisfactory covariate showed an increase in the predicted genetic value of the individuals, and with the phenotypic adjustment, only $67 \%$ were found in the original data set (Table 3 ). It can also be observed that the ordering of the adjusted data has changed.

The absence of competition caused by failures shows that the values of the predicted genetic effect are underestimated and the genetic material close to this fault cannot compensate for the lack of plants (Figure 1). Genetic materials may present differentiated aptitudes with or without growth enhancement, caused by lack of competition from the failures (Pavan et al., 2012). This was detected in this progeny test for age 20, but Ishibashi et al. (2017) verified this same behavior in a test at age 10 years in four places.

Table 3. Classification of the thirty best individuals by genetic effects for diameter at breast height (DBH) without and with adjustment and for Modified Failure Index in a P. taeda progeny test with 20 years, planted in Rio Negrinho, State of Santa Catarina.

\begin{tabular}{|c|c|c|c|c|c|c|c|}
\hline \multicolumn{4}{|c|}{ WITHOUT ADJUSTMENTS } & \multicolumn{4}{|c|}{ WITH ADJUSTMENTS } \\
\hline BL & FAM & ARV & a & BL & FAM & ARV & A \\
\hline 3 & 94 & 1 & 5.4248 & 3 & 94 & 1 & 6.1684 \\
\hline 4 & 91 & 3 & 4.7089 & 5 & 94 & 5 & 5.0368 \\
\hline 5 & 94 & 5 & 4.1121 & 4 & 91 & 3 & 4.6095 \\
\hline 5 & 76 & 5 & 3.9721 & 2 & 94 & 5 & 4.3443 \\
\hline 3 & 74 & 1 & 3.7385 & 3 & 94 & 4 & 4.2543 \\
\hline 1 & 53 & 2 & 3.7280 & 5 & 76 & 5 & 4.0964 \\
\hline 3 & 94 & 4 & 3.6836 & 5 & 94 & 3 & 3.9578 \\
\hline 1 & 110 & 3 & 3.6711 & 2 & 94 & 4 & 3.9065 \\
\hline 2 & 46 & 3 & 3.6013 & 1 & 57 & 3 & 3.9040 \\
\hline 1 & 118 & 4 & 3.5469 & 4 & 94 & 2 & 3.7999 \\
\hline 2 & 94 & 5 & 3.5022 & 3 & 94 & 2 & 3.7952 \\
\hline 2 & 10 & 3 & 3.4898 & 1 & 94 & 4 & 3.7791 \\
\hline 2 & 94 & 4 & 3.3558 & 3 & 74 & 1 & 3.7140 \\
\hline 1 & 68 & 5 & 3.3488 & 5 & 94 & 1 & 3.6343 \\
\hline 4 & 118 & 1 & 3.3335 & 3 & 94 & 5 & 3.6046 \\
\hline 4 & 94 & 2 & 3.3038 & 1 & 22 & 2 & 3.5868 \\
\hline 2 & 118 & 4 & 3.2969 & 5 & 94 & 2 & 3.5401 \\
\hline 3 & 94 & 2 & 3.2660 & 2 & 10 & 3 & 3.4668 \\
\hline 1 & 116 & 5 & 3.2529 & 3 & 37 & 3 & 3.4450 \\
\hline 1 & 94 & 4 & 3.2347 & 5 & 94 & 4 & 3.3818 \\
\hline 1 & 118 & 1 & 3.2033 & 1 & 53 & 2 & 3.3664 \\
\hline 1 & 57 & 3 & 3.1802 & 1 & 68 & 5 & 3.3434 \\
\hline 4 & 118 & 5 & 3.1609 & 5 & 19 & 3 & 3.3379 \\
\hline 5 & 94 & 3 & 3.1305 & 4 & 94 & 4 & 3.3079 \\
\hline 4 & 94 & 4 & 3.1081 & 3 & 46 & 5 & 3.1789 \\
\hline 5 & 118 & 3 & 3.0640 & 2 & 46 & 3 & 3.1542 \\
\hline 2 & 30 & 3 & 3.0512 & 2 & 3 & 5 & 3.1461 \\
\hline 5 & 10 & 3 & 3.0430 & 1 & 94 & 2 & 3.1142 \\
\hline 3 & 94 & 5 & 3.0210 & 3 & 80 & 2 & 3.0937 \\
\hline 1 & 22 & 2 & 3.0100 & 5 & 10 & 3 & 3.0674 \\
\hline
\end{tabular}

Where: BL: block, FAM: family, ARV: tree, a: predicted genetic effect 
Resende Junior et al. (2012), studying growth in commercial populations of eucalyptus clones, found that a specific replicate clone demonstrated the potential of differential competition when compared to other clones, and could be affected by spacing between tree plants and environmental characteristics. In the test evaluated by Ishibashi et al. (2017), the spacing used was $2.5 \times 2 \mathrm{~m}$, and the presence of competition among individuals was detected at 10 years of age, and mortality was not determinant in the authors' experiment.

In this study, with spacing of $2.5 \times 2.5 \mathrm{~m}$, no competition was identified at the same age. One hypothesis to be evaluated in future studies is the observation of competition in different spacings for the same genetic materials, so one can verify if the spacing acts directly on the components of variance and genetic parameters.

\begin{tabular}{|c|c|c|c|c|c|c|c|c|c|c|c|c|c|c|c|c|c|c|c|}
\hline 0 & $X$ & $X$ & $X$ & $X$ & $X$ & $X$ & $X$ & $X$ & $X$ & $X$ & $X$ & $X$ & $X$ & $X$ & $X$ & $X$ & $X$ & $X$ & $x$ \\
\hline$X$ & $X$ & $X$ & 0 & $X$ & $X$ & $X$ & 0 & 0 & $X$ & $X$ & $X$ & 0 & $x$ & $X$ & 0 & 0 & $X$ & 0 & $X$ \\
\hline$X$ & $X$ & $X$ & $X$ & $X$ & $X$ & $X$ & $X$ & $X$ & $X$ & $X$ & $X$ & $X$ & $X$ & $X$ & $X$ & $X$ & 0 & $X$ & $X$ \\
\hline$X$ & 0 & $X$ & $x$ & 0 & $X$ & $X$ & $X$ & 0 & $X$ & $X$ & $X$ & $X$ & $X$ & $x$ & 0 & $X$ & $X$ & 0 & $X$ \\
\hline$X$ & $X$ & $X$ & $X$ & 0 & $X$ & $x$ & $X$ & $X$ & $X$ & $X$ & $X$ & $X$ & $x$ & 0 & $X$ & $X$ & 0 & $X$ & $X$ \\
\hline 0 & $X$ & $X$ & $X$ & $X$ & $X$ & $X$ & $X$ & $X$ & $X$ & $X$ & $X$ & $X$ & $X$ & $X$ & $X$ & $X$ & 0 & 0 & $x$ \\
\hline$X$ & $X$ & $X$ & $X$ & $X$ & $X$ & $X$ & $X$ & $X$ & $X$ & $X$ & $X$ & $X$ & $X$ & $X$ & $X$ & 0 & 0 & $X$ & $X$ \\
\hline$X$ & $X$ & $X$ & $x$ & $X$ & $X$ & $X$ & $X$ & $X$ & $X$ & $X$ & $X$ & 0 & 0 & 0 & 0 & $X$ & $X$ & $x$ & $X$ \\
\hline 0 & 0 & $X$ & 0 & 0 & $X$ & $X$ & $X$ & $X$ & $X$ & $X$ & 0 & $X$ & $X$ & $X$ & $X$ & $X$ & $X$ & $X$ & 0 \\
\hline$X$ & $X$ & $X$ & $X$ & $X$ & $X$ & $X$ & $X$ & 0 & $X$ & $X$ & $X$ & $X$ & $x$ & $X$ & $X$ & $X$ & $X$ & $x$ & 0 \\
\hline$X$ & $X$ & $X$ & $X$ & $X$ & $X$ & $X$ & $X$ & $X$ & $X$ & $X$ & $X$ & $X$ & $X$ & 0 & $X$ & $X$ & $X$ & 0 & $X$ \\
\hline$X$ & $X$ & 0 & 0 & 0 & $X$ & $X$ & $X$ & $X$ & $X$ & $X$ & $X$ & $X$ & $X$ & $x$ & $X$ & $X$ & $X$ & $X$ & $X$ \\
\hline & \multicolumn{19}{|c|}{ Subtitle } \\
\hline 0 & \multicolumn{19}{|c|}{ Failure } \\
\hline$x$ & \multicolumn{19}{|c|}{ Selected individual after adjustment } \\
\hline $\mathrm{X}$ & \multicolumn{19}{|c|}{ Selected individual before and after adjustment } \\
\hline$x$ & \multicolumn{19}{|c|}{ Selected individual before adjustment } \\
\hline
\end{tabular}

Figure 1. Detail of the progeny test which demonstrates the individuals that would be selected before the adjustment, after the adjustment and which remains selected after the data adjustment.

Belaber et al. (2019) used an auto-regressive mixed spatial model to estimate genetic parameters of 429 P. elliottii open pollinated families and to adjust the phenotypic values and observed a considerable improvement in the data after the adjustment, since the spatial analysis significantly reduced the variation residual, a fact also observed by Ye and Jayawickrama (2008) and Cappa et al, (2015).

Nunes et al., (2018), studying a clonal eucalyptus test in single tree-plots in the initial phases and square plots in the final stages, observed that the competition effect acts directly on the individuals in the final phase. Therefore, evaluation of the competitive effect should be performed in genetic and clonal tests to ensure an adequate and efficient selection. As shown by the afore-mentioned authors, this adjustment for competition should occur from the moment the competition interferes in the selection of the genetic material, corroborating this work. Therefore, spatial analysis and adjustment of phenotypic models should be included in the routine procedure in the analysis of genetic tests, to ensure the predicted genetic gains for the next generation.

Broad genomic selection is a tool that should be incorporated into breeding programs for forest species. Incorporating genomic selection could drastically reduce the time required to complete a breeding cycle, eliminating the testing phase, significantly accelerating genetic 
gain over traditional breeding (Resende Junior et al., 2012). It can also assist directly with data adjustment and correction for efficient selection in a shorter time and with accuracy.

\section{CONCLUSION}

Competition affects growth in diameter at breast height in the $P$. taeda progeny test at more advanced ages. In younger conditions, no adjustments are needed to correct the competition effect.

The evaluation at 20 years of age detected the need to make adjustments to correct for the competition effect. The covariate Modified Failure Index among the six tested was the only one that corrected the effect of competition at age 20. The use of covariate in the adjustment of phenotypic models is an important tool within genetic breeding programs, since it improves the efficiency of genetic material selection for the next generation of breeding.

\section{ACKNOWLEDGMENTS}

Our thanks to Conselho Nacional de DesenvolvimentoCientífico e Tecnológico (National Council for Scientific and Technological Development - CNPq), Coordenação de Aperfeiçoamento de Pessoal de Nível Superior (Coordination of Improvement of Higher Education Personnel - CAPES) and Valor Florestal for the support during the development of this work.

\section{REFERENCES}

Alvares, C. A., Stape, J. L., Sentelhas, P. C., Moraes, G., Leonardo, J., \& Sparovek, G. (2013). Köppen's climate classification map for Brazil. Meteorologische Zeitschrift, 22(6), 711-728. http://dx.doi.org/10.1127/0941-2948/2013/0507.

Belaber, E. C., Gauchat, M. E., Rodríguez, G. H., Borralho, N. M., \& Cappa, E. P. (2019). Estimation of genetic parameters using spatial analysis of Pinus elliottiiEngelm. var. elliottiisecond-generation progeny trials in Argentina. New Forests, 50(4), 605-627. http://dx.doi.org/10.1007/s11056-018-96820 .

Bognola, I. A., Ribeiro Junior, P. J., Silva, E. A. A., Lingnau, C., \& Higa, A. R. (2008). Modelagem uni e bivariada da variabilidade espacial de rendimento de Pinus taeda L. Floresta, 38(2), 373-385. http://dx.doi.org/10.5380/rf.v38i2.11632.

Cappa, E. P., Stoehr, M. U., Xie, C.-Y., \& Yanchuk, A. D. (2016). Identification and joint modeling of competition effects and environmental heterogeneity in three Douglas-fir (Pseudotsugamenziesii var. menziesii) trials. Tree Genetics \& Genomes, 12(6), 102. http://dx.doi.org/10.1007/s11295-016-1061-4.

Cappa, E. P., Yanchuk, A. D., \& Cartwright, C. V. (2015). Estimation of genetic parameters for height using spatial analysis in Tsuga heterophylla full-sibling family trials in British Columbia. Silvae Genetica, 64(1-6), 59-73. http://dx.doi.org/10.1515/sg-2015-0005.

Costa, R. B., Resende, M. D. V., Gonçalves, P. S., Chichorro, J. F., \& Roa, R. A. R. (2008). Variabilidade genética e seleção para caracteres de crescimento da seringueira. Bragantia, 67(2), 299-305. http://dx.doi.org/10.1590/S0006-87052008000200005.

Coutinho, R. T., Bespalhok Filho, J. C., Fritsche Neto, R., \& Caroline Frizzo, C. (2017). Viabilidade da seleção precoce de Pinus taeda L. em diâmetro a altura do peito em programa de melhoramento genético. Scientia Forestalis, 45(113), 205-219. http://dx.doi.org/10.18671/scifor.v45n113.21.

Empresa Brasileira de Pesquisa Agropecuária - EMBRAPA. Centro Nacional de Pesquisa de Solos. (2006). Sistema brasileiro de classificação de solos (2. ed. rev.). Brasília: EMBRAPA.

Farias Neto, J. T., Clement, C. R., \& Resende, M. D. V. (2013). Estimativas de parâmetros genéticos e ganho de seleção para produção de frutos em progênies de polinização aberta de pupunheira no Estado do Pará, Brasil. Bragantia, 72(2), 122-126. http://dx.doi.org/10.1590/S000687052013000200002.

Ishibashi, V., Martinez, D. T., \& Higa, A. R. (2017). Phenotypic models of competition for Pinus taeda L. genetic parameters estimation. Cerne, 23(3), 349-358. http://dx.doi.org/10.1590/01047760201723032365.

Leonardecz-Neto, E., Vencovsky, R., \& Sebbenn, A. M. (2003). Ajuste para a competição entre plantas em teste de progênies e procedências de essências florestais. Scientia Forestalis, (63), 136-149. 
Martinez, D. T., Resende, M. D. V., Costa, R. B., Higa, A. R., Santos, G. A., \& Fier, I. S. N. (2012). Estudo da interação genótipo $\mathrm{x}$ ambiente em progênies de Pinus taeda por meio da análise de parâmetros genéticos. Floresta, 42(3), 539-552. http://dx.doi.org/10.5380/rf.v42i3.20115.

Nunes, A. C. P., Santos, O. P., Santos, G. A., \& Resende, M. D. V. (2018). Statisticalstrategies design basedoncompetition classes of Eucalyptus clones. Industrial Crops and Products, 124, 66-73. http://dx.doi.org/10.1016/j.indcrop.2018.07.026.

Pallant, J. (2010). SPSS survival manual: a step by step guide to data analysis using SPSS. Maidenhead: Allen \& Unwin Australia.

Pires, I. E., Resende, M. D. V., Silva, R. L., \& Resende Júnior, M. F. R. (2011). Genética florestal. Viçosa: UFV.

Pavan, B. E., Paula, R. C., Perecin, D., Candido, L. S., \& Scarpinati, E. A. (2012). Efeito competicional em testes de progênies de eucalipto. Ciência Florestal, 22(3), 433-443. http://dx.doi.org/10.5902/198050986612.

Ramalho, M. A. P., Ferreira, D. F., \& Oliveira, A. C. (2012). Experimentação em genética e melhoramento de plantas (3. ed.). Lavras: Editora UFLA.

Resende Junior, M. F. R., Munõz, P., Acosta, J. J., Peter, G. F., Davis, J. M., Grattapaglia, D., Resende, M. D. V., \& Kirst, M. (2012). Accelerating the domestication of trees using genomic selection: accuracy of prediction models across ages and environments. The New Phytologist, 193(3), 617-624. PMid:21973055. http://dx.doi.org/10.1111/j.1469-8137.2011.03895.x.

Resende, M. D. V. (2007a). Selegen-Reml/Blup: sistema estatístico e seleção genética computadorizada via modelos lineares mistos. Colombo: Embrapa Florestas.

Resende, M. D. V. (2007b). Matemática e estatística na análise de experimentos e no melhoramento genético. Colombo: Embrapa Florestas.

Resende, M. D. V. (2002). Genética biométrica e estatística no melhoramento de plantas perenes (975p). Brasília: Embrapa. Informação Tecnológica.

Ye, T. Z., \& Jayawickrama, K. J. S. (2008). Efficiency of using spatial analysis in first-generation coastal Douglas-fir progeny tests in the US Pacific Northwest. Tree Genetics \& Genomes, 4(4), 677-692. http://dx.doi.org/10.1007/s11295-008-0142-4.

Author's contributions: PCF): conceptualization, data curation, formal analysis, investigation, methodology, writing - original draft software, writing - review \& editing, Vl: conceptualization, data curation, formal analysis, investigation, methodology, JLMM: validation, visualization, DTM: validation, visualization, ARH: conceptualization, funding acquisition, project administration, validation, visualization. 